\title{
Estimation of genetic parameters and (co)variance components for weaning traits of Charolais population in Hungary*
}

\begin{abstract}
Weaning performance of 10808 purebred offsprings (4991 male and 5817 female) of 80 sires in 13 farms were analised using animal model. Heritability, breeding value, (co)variance components for weaning weight (WW), preweaning daily gain (PDG), 205-day weight (CWW) were calculated. Farm, parity, year of birth, season of birth, sex were treated as fixed, and the maternal permanent environment was treated as random effects. In case of WW and PDG, the age of the calves at weaning was fitted as a covariant. Data were analyzed with MTDFREML (Boldman et al. 1993) program. The overall mean value and standard deviation of WW, PDG and CWW were $221 \pm 47 \mathrm{~kg}, 1,111 \pm 0.21 \mathrm{~kg} /$ day and $226 \pm 42 \mathrm{~kg}$, respectively. The age of the calves at weaning was 202 days. The direct heritability $\left(\mathrm{h}_{\mathrm{d}}^{2}\right)$ of WW and PDG were $0.57 \pm 0.08,0.49 \pm 0.07$ and CWW was $0.44 \pm 0.06$, respectively. The maternal heritability $\left(\mathrm{h}_{\mathrm{m}}^{2}\right)$ of these traits were $0.32 \pm 0.09,0.33 \pm 0.10$ and $0.33 \pm 0.09$, respectively. The direct-maternal correlations $\left(\mathrm{r}_{\mathrm{dm}}\right)$ were strong and negative. The medium heritability estimates for direct effects suggest that progeny tests should be used in this population to increase genetic improvement.
\end{abstract}

Key Words: beef cattle; genetic parameters; breeding value; Charolais

\section{Zusammenfassung}

Titel der Arbeit: Schätzung genetischer Parameter und (Ko) Varianzkomponenten von Absetzergebnissen ungarischer Charolais

Es wurden die Absetzergebnisse von 4991 männlichen und 5817 weiblichen Charolaiskälbern aus 13 Betrieben ausgewertet. Unter Nutzung des Tiermodells wurden die Heritabilität, die Zuchtwerte und die (Ko)Variantenkomponenten der Merkmale Absetzgewicht (WW), tägliche Zunahme vor dem Absetzten (PDG) und das auf 205 Tage korrigierte 205 Tagegewicht (CWW) einbezogen. Im Modell wurden die fixen Effekte Betrieb, Zahl der Abkalbungen, Jahrgang, Jahreszeit und der zufällige Effekt Mutter als Umweltfaktor, bei den Parametern WW und PDG ist das Alter des Kalbes als Kovariante berücksichtigt. Die Daten wurden mit dem Modell MTDFREML (BOLDMANN et al., 1993) ausgewertet. Das durchschnittliche Absetzalter betrug 202 Tage. Die Durchschnittswerte und Standardabweichungen der untersuchten Merkmale lagen bei $221 \pm 47 \mathrm{~kg}$ für WW, $1,11 \pm 0,21 \mathrm{~kg} /$ Tag für PDG und $226 \pm 42 \mathrm{~kg}$ für CWW. Die Schätzwerte für die Heritabilität $\left(\mathrm{h}^{2}{ }_{\mathrm{d}}\right)$ betrugen für WW, PDG bzw. CWW 0,57 $\pm 0,08,0,49 \pm 0,07$ bzw. $0,44 \pm 0,06$ und für die mütterliche Heritabilität $\left(\mathrm{h}^{2} \mathrm{~m}\right)$ in der gleichen Merkmalsfolge 0,32 $\pm 0,09,0,33 \pm 0,10$ bzw. 0,33 $\pm 0,09$. Die direkten maternalen Korrelationen $\left(\mathrm{r}_{\mathrm{dm}}\right)$ zeigten bei allen Merkmalen stark negative Zusammenhänge. Die ermittelten Heritabilitätsschätzwerte lassen, bei Einbeziehung dieser Merkmale in die Nachkommenschaftsprüfung, einen Zuchtfortschritt erwarten.

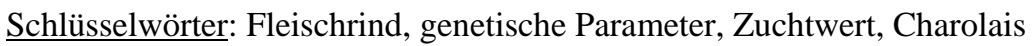

\section{Introduction}

Weaned beef calves are the products of beef cattle sector, therefore the results are influenced by weaning weight. On the other hand the weaning weight expresses the calf rearing ability of cows, so changes in weaning weight are important factors at selection. However there are results about variation and genetic parameters of the most important beef traits of dairy and dual purpose breeds (ATIL et al., 2005; JACUBEC 
et al., 2003; CANTET et al., 2003; GOYACHE et al., 2002; REINSCH and KALM, 1995) it is important requirement to estimate the breeding value based on weaning results very exactly.

NELSEN and KRESS (1981) found that sex and the age of dam influenced the weaning weight of Aberdeen Angus and Hereford herds $(\mathrm{P}<0.01)$. JAKUBEC et al. (2000) showed that year, sex and the age of dam influenced the weaning weight and daily gain of Aberdeen Angus calves $(\mathrm{P}<0.01)$. GÁSPÁRDY et al. (1998) analysed the weaning weight of Charolais calves. They found that parity (number of calving) and year of birth had an effect on the adjusted 205-day weight. MASSEY and BENYHSEK (1981) in a crossbreed population showed the effect of dam's age on weaning performance. According to SZABÓ and GAJDI (1993) age of dam, sex, year and season had significant effect on 205-day weight of Hereford calves.

SZABÓ (1993) summarized the results of 35 publications and reported that heritability of calf's daily gain before weaning was 0.27 on average. Heritability of weaning weight was 0.30 on average according to 61 publications. BOURDON and BRINKS (1982) found that heritability of the preweaning daily gain and weaning weight was 0.60 and 0.63 , respectively. LEE et al. (1997a) examined the weaning weight of Simmental calves. They found that the direct heritability $\left(\mathrm{h}_{\mathrm{d}}{ }_{\mathrm{d}}\right)$ of weaning weight was 0.21, maternal heritability $\left(\mathrm{h}_{\mathrm{m}}^{2}\right)$ was 0.10. MASSEY and BENYHSEK (1981) found that heritability of the 205-day weight and preweaning daily gain was 0.11 and 0.08 , respectively. SZABÓ et al. (2001) showed that heritability of weaning weight was 0.29. DUANGJINDA et al. (2001) examined the heritability value of weaning weight in Charolais herds. They found that direct heritability of weaning weight was 0.33 , maternal heritability was 0.15 . VAN VLECK at al. (1996) found that direct heritability of weaning weight was 0.16 and maternal heritability was 0.12 , respectively. TÖZSÉR et al. (2002) showed that heritability of weaning weight of Limousin calves was 0.14 and CANTET et al. (2003) found $\mathrm{h}^{2}=0.32$ in Angus beef cattle.

Correlation between direct genetic and maternal effects $\left(r_{d m}\right)$ is different. DODENHOFF at al. (1999) examined the genetic parameters of weaning weight in five different breeds. They found that the direct-maternal correlation varied between 0.10 and -0.37 . BASCHNAGEL et al. (1998) found that the direct-maternal correlation was -0.50 for Angus in Sweden. MEYER (1992) showed that the direct maternal correlation of weaning weight was -0.59. NUNEZ-DOMINGUEZ at al. (1993) found high positive direct-maternal correlation $\left(\mathrm{r}_{\mathrm{dm}}=+0.63\right)$ in the case of weaning weight. VAN VLECK et al. (1996) showed that the direct-maternal correlation of the weaning weight was 0.40 .

There have not been any investigations in connection with covariance and genetic parameter estimation in Hungarian beef population so far. That is the reason why analyes of genetic parameters and breeding value of the Hungarian Charolais population were carried out using animal model.

\section{Material and Methods}

Field records were provided by the Association of Hungarian Charolais Breeders. The weaning results of 10808 pure bred calves (4991 male and 5817 female) born from 5388 cows mated with 80 sires were analyzed. 36 of the sires with more than 100 
offsprings were presented. There were Hungarian and French origin sires used in this population. Description of the samples is shown in Table 1.

Estimated traits were the weaning weight (WW), preweaning daily gain (PDG) and 205-day weight (CWW).

Table 1

Characteristic of the samples for univariate analyses (Charakteristik der einbezogenen Daten)

$\begin{array}{cc}\text { Number of animals in total } & 16117 \\ \text { Number of records in data } & 10808 \\ \text { Sire } & 80 \\ \text { Dam } & 5388 \\ \text { Paternal grand sires } & 14 \\ \text { Maternal grand sires } & 25 \\ \text { Grand sires together } & 39 \\ \text { Paternal grand dams } & 23 \\ \text { Maternal grand dams } & 121 \\ \text { Grand dams together } & 144 \\ \text { Calf whithout performance } & 47\end{array}$

Genetic parameters (variance, heritability) and breeding values (EBV= Estimated Breeding Value) were predicted with single-trait animal model, using the following equation:

\section{$\mathbf{y}=\mathbf{X b}+\mathbf{Z u}+\mathbf{W m}+\mathbf{S p e}+\mathbf{e}$}

where, $\mathbf{y}$ is a N X 1 vector of observation, $\mathbf{b}$ denotes the vector of fixed effects (herd, parity, year, season and sex), $\mathbf{X}$ is the matrix that associates b with $\mathbf{y}$; $\mathbf{u}$ is the vector of breeding values for direct genetic effects, $\mathbf{Z}$ is the matrix that associates $\mathbf{u}$ with $\mathbf{y} ; \mathbf{m}$ is the vector of breeding values for maternal genetic effects, $\mathbf{W}$ is the matrix that associates $\mathrm{m}$ with $\mathrm{y}$; pe is the vector of permanent environmental effects contributed by dams to records of their progeny, $\mathbf{S}$ is the matrix that associates pe with $\mathbf{y}$; and $\mathbf{e}$ is the vector of random residual effects.

It is assumed that

$\operatorname{var}\left(\begin{array}{l}\mathrm{b} \\ \mathrm{m} \\ \mathrm{pe} \\ \mathrm{e}\end{array}\right)=\left(\begin{array}{llll}\mathrm{g}_{11} \mathbf{A} & \mathrm{g}_{12} \mathbf{A} & 0 & 0 \\ \mathrm{~g}_{21} \mathrm{~A} & \mathrm{~g}_{22} \mathrm{~A} & 0 & 0 \\ 0 & 0 & \mathrm{I}^{2} & 0 \\ 0 & 0 & 0 & \mathrm{I}_{\mathrm{e}}^{2}\end{array}\right)$

where $\mathbf{A}$ is the numerator relationship matrix and the $\mathbf{I}$ are identity matrices of appropriate order.

The levels of fixed effects were as follows: 13 levels for farm, 14 levels for parity, 16 levels for year of birth (1987-2002), 4 levels for season (1, December-February; 2, March-May; 3, June-August; 4, September-November) and 2 levels for sex.

Total heritability $\left(\mathrm{h}_{\mathrm{T}}^{2}\right)$ defined as (e.g. WILLHAM, 1972) $\mathrm{h}_{\mathrm{T}}{ }_{\mathrm{T}}=\left(\sigma_{\mathrm{d}}{ }_{\mathrm{d}}+0,5{\sigma_{\mathrm{m}}}^{2}+1,5 \sigma_{\mathrm{dm}}\right)$ $/ \sigma_{\mathrm{p}}^{2}$ were calculated.

The genetic parameters, (co)variance components and breeding values were estimated with MTDFREML (BOLDMAN et al. 1993) program. Iteration were stopped when the variance of function values $(-2 \log \mathrm{L})$ in the simplex were less than $1 \times 10^{-9}$. 


\section{Results and Discussion}

Genetic parameters and (co)variances

The estimated genetic parameters and (co)variance components of the investigated traits are shown in Table 2.

Table 2

The estimated (co)variance components and genetic parameters ((Ko)Varianzen und genetische Parameter der untersuchten Merkmale)

\begin{tabular}{cccc}
\hline Parameters & Weaning weight & Preweaning daily gain* & 205-day weight \\
\hline$\sigma^{2}$ & 791 & 0.0172 & 680 \\
$\sigma_{\mathrm{m}}^{2}$ & 438 & 0.0113 & 517 \\
$\sigma_{\mathrm{dm}}$ & -558 & -0.0131 & -574 \\
$\sigma_{\mathrm{pe}}^{2}$ & 73 & 0.0016 & 66 \\
$\sigma_{\mathrm{e}}^{2}$ & 633 & 0.0179 & 861 \\
$\sigma^{2}$ & 1377 & 0.0348 & 1550 \\
$\mathrm{~h}_{\mathrm{p}}^{2}$ & $0.57 \pm 0.081$ & $0.49 \pm 0.076$ & $0.44 \pm 0.066$ \\
$\mathrm{~h}_{\mathrm{d}}^{2}$ & $0.32 \pm 0.094$ & $0.33 \pm 0.10$ & $0.33 \pm 0.098$ \\
$\mathrm{r}_{\mathrm{dm}}$ & $-0.95 \pm 0.07$ & $-0.94 \pm 0.083$ & $-0.97 \pm 0.080$ \\
$\mathrm{c}^{2}$ & $0.053 \pm 0.05$ & $0.046 \pm 0.06$ & $0.043 \pm 0.06$ \\
$\mathrm{e}^{2}$ & $0.46 \pm 0.06$ & $0.51 \pm 0.06$ & $0.55 \pm 0.05$ \\
$\mathrm{~h}_{\mathrm{m}}{ }_{\mathrm{m}}{ }^{2} \mathrm{c}^{2}$ & 0.37 & 0.38 & 0.37 \\
$\mathrm{~h}_{\mathrm{T}}^{2}$ & 0.047 & 0.092 & 0.050 \\
\hline
\end{tabular}

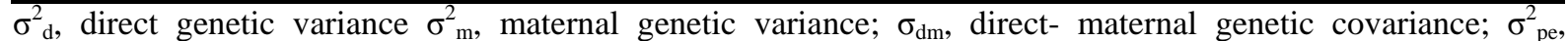
maternal permanent environmental effect; $\sigma_{\mathrm{e}}^{2}$, residual variance; $\sigma_{\mathrm{p}}^{2}$, phenotypic variance; $\mathrm{h}_{\mathrm{d}}^{2}$, direct heritability; $\mathrm{h}_{\mathrm{m}}^{2}$, maternal heritability; $\mathrm{r}_{\mathrm{dm}}$, direct-maternal genetic correlations; $\mathrm{c}^{2}$, the ratio of the permanent environmental variance to the phenotypic variance; $\mathrm{e}^{2}$, the ratio of the residual variance to the phenotypic variance; $\mathrm{h}^{2}$, total heritability

* estimated in $\mathrm{kg} /$ day

Direct heritability $\left(\mathrm{h}_{\mathrm{d}}^{2}\right)$ of weaning weight, preweaning daily gain and 205-day weight were $0.57 \pm 0.081,0.49 \pm 0.076$ and $0.44 \pm 0.066$, respectively. High estimates of direct heritability for the investigated traits may be due to the used foreign sires, which are increasing the direct additive genetic variance. Maternal heritability $\left(\mathrm{h}_{\mathrm{m}}^{2}\right)$ in the case of these traits were $0.32 \pm 0.094,0.33 \pm 0.10$ and $0.33 \pm 0.098$.

Direct- maternal genetic correlations were high and negative $\left(\mathrm{r}_{\mathrm{dm}}=-0.95 \pm 0.07\right.$, $0.94 \pm 0.083,-0.97 \pm 0.080$ ). These data in results were higher than the estimates of DODENHOFF (1999) -0.12, PHOCAS and LALOË (2003) -0.19, and DUANGJINDA et al. (2001) -0.46, but MEYER (1992) in the case of Zebu Cross found that the direct-maternal genetic correlation of weaning weight -0.78 .

Total heritability $\left(\mathrm{h}_{\mathrm{T}}^{2}=0.047,0.092,0.050\right)$ was low due to the high negative direct maternal genetic correlation. The ratio of the permanent environmental variance $\left(c^{2}\right)$ was low (4-6\%). Similar results were found by BASCHNAGEL et al. (1998) for Angus in Sweden, CARNIER et al. (2000) for Piedmontese in Italy, DUANGJINDA et al. (2001) for Gelbvieh, LEE et al. (1997b) for Simmental and VAN VLECK et al. (1996) for Simmental in USA. The residual variance were similar for the three traits. The ratio to the phenotypic variance $\left(\mathrm{e}^{2}\right)$ ranged from 46 to $55 \%$.

Breeding values

Table 3 shows the breeding values of the 36 examined sires, with more than 100 offsprings. The best sire was the registered by number $32500(+66.51 \mathrm{~kg}$ in weaning weight, $+0.304 \mathrm{~kg} /$ day in preweaning daily gain and $+76.89 \mathrm{~kg}$ in 205-day weight). The worst sire was of the number $9823(-46.1 \mathrm{~kg},-0.179 \mathrm{~kg} / \mathrm{day}$ and $-42.35 \mathrm{~kg}$ in the 
case of WW, PDG and CWW). Figure 1 and 2 show the overall breeding values of the Hungarian and French Charolais sires. Direct effect of French sires was higher than that of the Hungarian Charolais sires that explains the relatively high direct additive genetic variance. That means that French Charolais sires are genetically better as for the growing capacity than Hungarian ones. As both French and Hungarian Charolais sires had negative maternal EBV values, maternal genetic effect could be increased in order to make further improvement on the genetic merit of the population values.

The medium heritability estimates for direct effects suggest that progeny tests should be used to increase genetic improvement.

Table 3

Estimated breeding values of the investigated traits (Bullenzuchtwerte der untersuchten Merkmale)

\begin{tabular}{|c|c|c|c|c|c|c|c|}
\hline \multirow[t]{2}{*}{ Sire } & \multirow{2}{*}{$\begin{array}{c}\text { Number of } \\
\text { progeny }\end{array}$} & $\begin{array}{l}\text { WW } \\
\text { direct }\end{array}$ & $\begin{array}{c}\text { WW } \\
\text { maternal }\end{array}$ & $\begin{array}{l}\text { PDG } \\
\text { direct }\end{array}$ & $\begin{array}{c}\text { PDG } \\
\text { maternal }\end{array}$ & $\begin{array}{l}\text { CWW } \\
\text { direct } \\
\end{array}$ & $\begin{array}{c}\mathrm{CWW} \\
\text { maternal }\end{array}$ \\
\hline & & \multicolumn{6}{|c|}{ Estimated breeding value } \\
\hline 9707 & 135 & 29.48 & -14.06 & 0.121 & -0.058 & 13.46 & -6.82 \\
\hline 9823 & 139 & -46.10 & 28.81 & -0.179 & 0.119 & -42.35 & 33.20 \\
\hline 10927 & 115 & 15.99 & -14.62 & 0.095 & -0.090 & 20.50 & -19.36 \\
\hline 10932 & 114 & 19.35 & -12.71 & 0.107 & -0.075 & 15.53 & -12.08 \\
\hline 10933 & 118 & 8.45 & -5.23 & 0.029 & -0.022 & 7.26 & -6.02 \\
\hline 11234 & 127 & 39.26 & -27.70 & 0.169 & -0.129 & 28.05 & -23.67 \\
\hline 11235 & 139 & -38.63 & 27.25 & -0.172 & 0.131 & -40.62 & 34.28 \\
\hline 11664 & 193 & -4.02 & 2.84 & -0.003 & 0.002 & -0.38 & 0.32 \\
\hline 11987 & 224 & -19.93 & 14.57 & -0.087 & 0.069 & -23.44 & 20.00 \\
\hline 11988 & 270 & -24.84 & 20.59 & -0.108 & 0.096 & -23.50 & 21.81 \\
\hline 12105 & 148 & 33.59 & -23.44 & 0.151 & -0.113 & 29.01 & -24.36 \\
\hline 12107 & 216 & 6.07 & -7.22 & 0.026 & -0.036 & 4.40 & -5.57 \\
\hline 12241 & 189 & -10.58 & 7.46 & -0.044 & 0.033 & -12.74 & 10.75 \\
\hline 12242 & 105 & -9.31 & 8.14 & -0.067 & 0.059 & -15.70 & 13.95 \\
\hline 12246 & 124 & 45.44 & -32.06 & 0.191 & -0.146 & 38.54 & -32.52 \\
\hline 12394 & 175 & -17.14 & 11.19 & -0.096 & 0.067 & -16.02 & 12.85 \\
\hline 12513 & 212 & -8.50 & 6.23 & -0.039 & 0.030 & -12.61 & 10.74 \\
\hline 12525 & 116 & -26.47 & 18.34 & -0.126 & 0.092 & -28.95 & 23.91 \\
\hline 12612 & 119 & 41.28 & -29.13 & 0.191 & -0.146 & 38.23 & -32.26 \\
\hline 12615 & 119 & 33.77 & -23.23 & 0.146 & -0.110 & 29.36 & -24.52 \\
\hline 12628 & 191 & -7.07 & 5.32 & -0.029 & 0.023 & -12.62 & 10.86 \\
\hline 12865 & 111 & -33.57 & 25.08 & -0.181 & 0.142 & -31.85 & 27.34 \\
\hline 12961 & 120 & 3.45 & -0.93 & -0.003 & 0.013 & -4.96 & 5.38 \\
\hline 13032 & 108 & 36.69 & -27.36 & 0.173 & -0.142 & 39.10 & -33.90 \\
\hline 13200 & 121 & -2.43 & 1.72 & -0.025 & 0.019 & -6.57 & 5.54 \\
\hline 13342 & 123 & 33.01 & -23.29 & 0.149 & -0.114 & 21.15 & -17.85 \\
\hline 13923 & 172 & 10.25 & -7.23 & 0.074 & -0.057 & 7.71 & -6.50 \\
\hline 13924 & 108 & 33.22 & -21.08 & 0.171 & -0.121 & 34.48 & -28.08 \\
\hline 14002 & 234 & 11.36 & -8.01 & 0.061 & -0.047 & 8.52 & -7.19 \\
\hline 14003 & 298 & -1.81 & 1.28 & -0.013 & 0.010 & -5.51 & 4.65 \\
\hline 14334 & 190 & 17.99 & -12.70 & 0.066 & -0.051 & 16.59 & -14.00 \\
\hline 14746 & 105 & 0.00 & 0.00 & 0.000 & 0.000 & 0.00 & 0.00 \\
\hline 14957 & 475 & 25.48 & -17.74 & 0.102 & -0.078 & 23.97 & -20.22 \\
\hline 32000 & 111 & 27.73 & -23.98 & 0.100 & -0.093 & 15.38 & -15.53 \\
\hline 32500 & 504 & 66.51 & -46.93 & 0.304 & -0.232 & 76.89 & -64.88 \\
\hline 33000 & 1894 & -3.75 & 2.65 & -0.024 & 0.019 & -1.34 & 1.13 \\
\hline
\end{tabular}




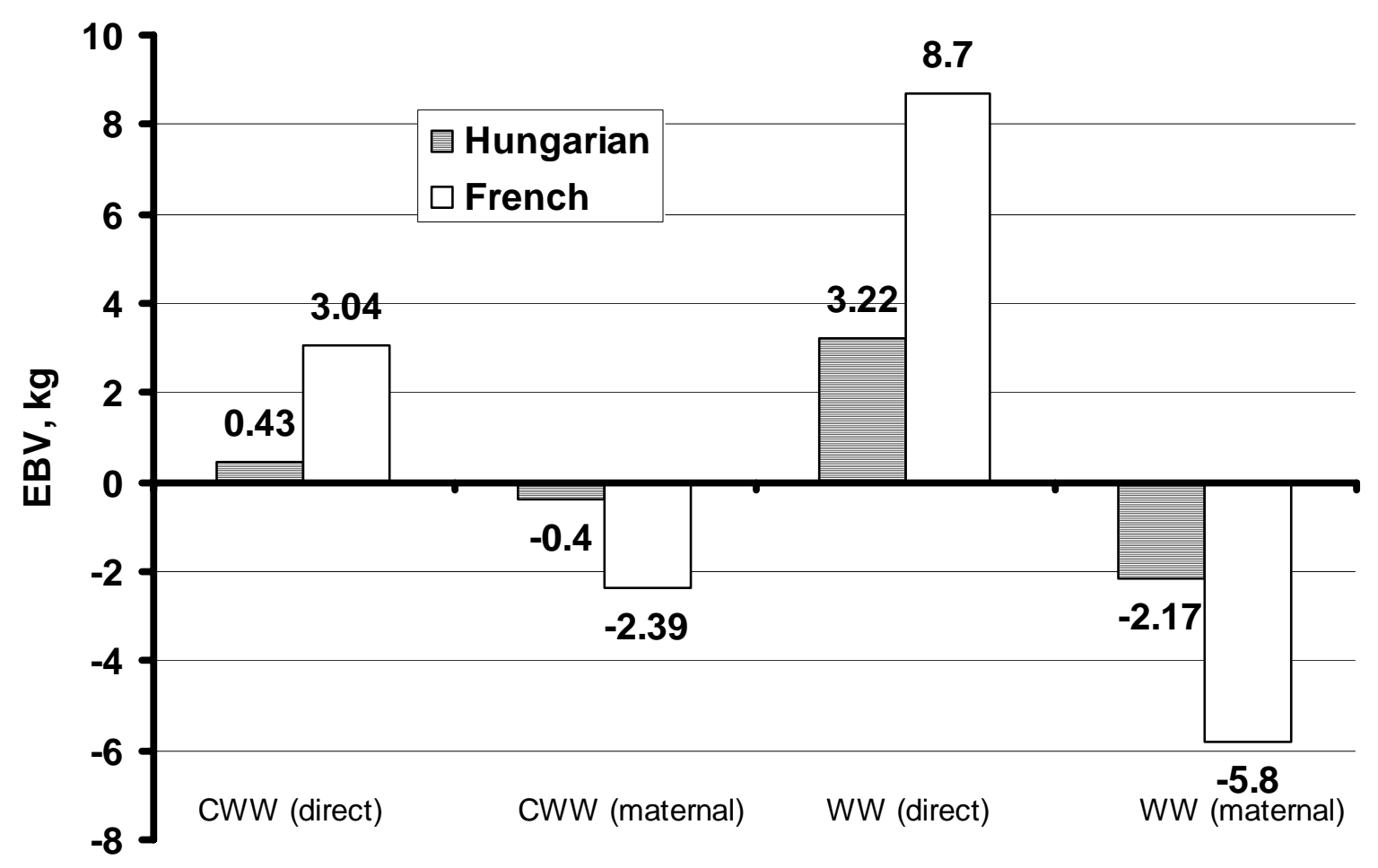

Fig. 1: Overall breeding value of the Hungarian and French Charolais sires in the case of weaning weight (WW) and 205-day weight (CWW) (Zuchtwerte der ungarischen und französischen Charolaisbullen für WW und CWW)

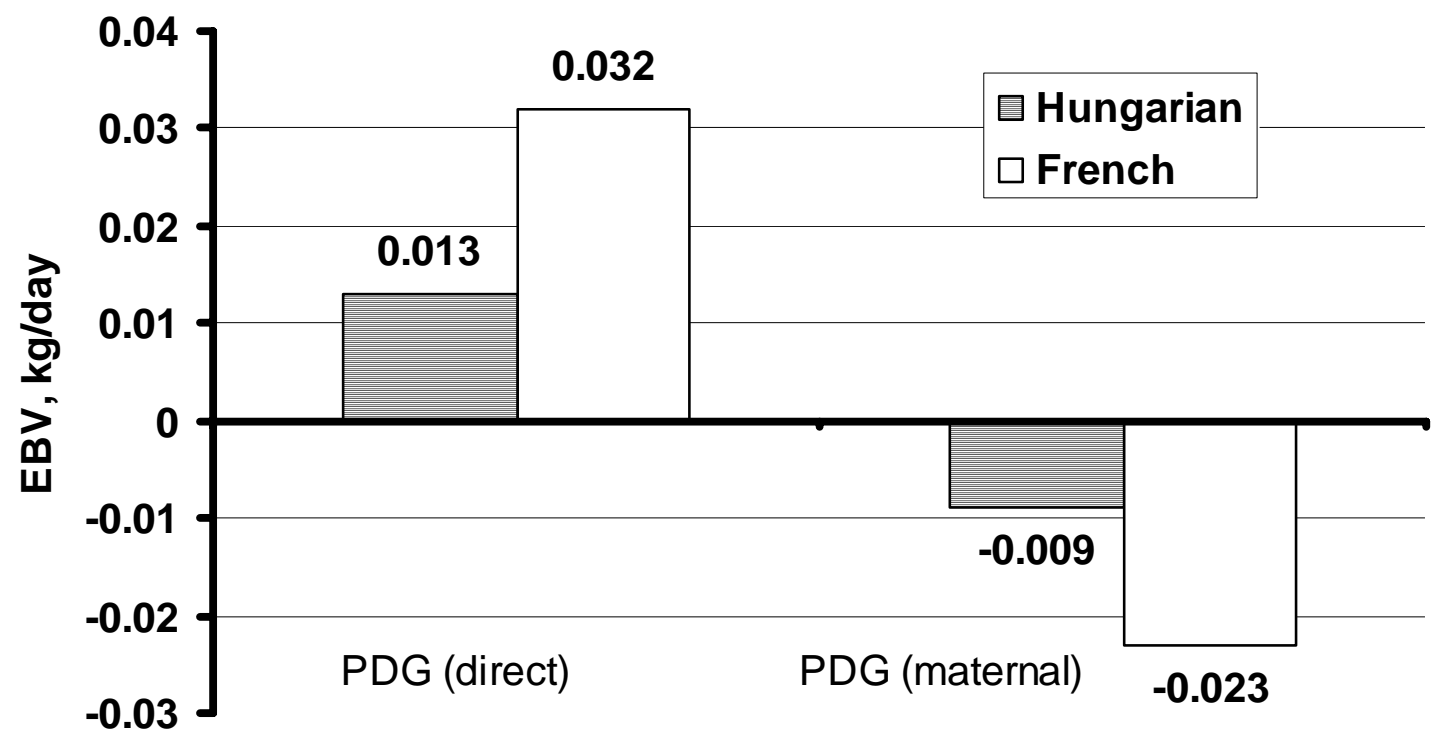

Fig. 2: Overall breeding value of the Hungarian and French Charolais sires in the case of preweaning daily gain (PDG) (Zuchtwerte der ungarischen und französischen Charolaisbullen für PDG)

Based on the results obtained it can be suggested that both the direct and maternal effect, because of the high negative direct and maternal genetic correlation, should be 
takeen into account during selection. It is assumed that the high genetic variance could contribute to a more succesful selection in the future.

\section{References}

ATIL, H.; KHATTAB, A. S.; BADAWY, L.:

Genetic parameter of birth and weaning weights for Friesian calves by using an animal model. Arch. Tierz., Dummerstorf 48 (2005), 261-269

BASCHNAGEL, B.M.; MOLL, J.; KÜNZI, N.:

Estimates of genetic parameters for weaning weight of Swiss Angus cattle fitting a sire $\mathrm{x}$ herd interaction as an additional random effect. 49th. Annual Meeting of the European Association for Animal Production. Warsaw, Poland. (1998) August, 24-27

BOLDMAN, K.G.; KRIESE, L.A.; VAN VLECK, L.D.; KACHMAN, S.D.:

A manual for use of MTDFREML. A set of programs to obtain estimates of variances and covariances. (1993) USDA-ARS, Clay Center, NE.

BOURDON, R.M.; BRINKS, J.S.:

Genetic, environmental and phenotypic relationships among gestation lenght, birth weight, growth traits and age at first calving in beef cattle. J. Anim. Sci., 55 (1982) 3, 543-553

CANTET, R.C.J.; STEIBEL, J.P.; BIRCHMEIER, A.N.; COLOMA, L.F.S.:

Bayesian estimation of genetic parameters for growth and carcass traits of grass-fed beef cattle by Full Conjugaste Gibbs. Arch. Tierz., Dummerstorf 46 (2003), 435-443

CARNIER, P., ALBERA, A., DAL ZOTTO, R., GROEN, A. F., BONA, M., BITTANTE, G.:

Genetic parameters for direct and maternal calving ability over parities in Piedmontese cattle. J. Anim. Sci., 78 (2000), 532-2539

CUBAS, A.C., BERGER, P.J., HEALEY, M.H.:

Genetic parameters for calving ease and survival at birth in Angus field data. J. Anim. Sci., 69 (1991) 10, 3952-3958

DODENHOFF, J.; VAN VLECK, L.D.; GREGORY, K. E.:

Estimation of direct, maternal and grandmaternal genetic effects for weaning weight in several breeds of beef cattle. J. Anim. Sci., 77 (1999) 4, 840-845

DUANGJINDA, M.; BERTRAND, J.K.; MISZTAL, I.; DRUET, T.:

Estimation of additive and nonadditive genetic variances in Hereford, Gelbvieh and Charolais by method R. J. Anim. Sci., 79 (2001), 2997-3001

GÁSPÁRDY, A.; SZABÁRA, L.; SVÁB, L.; BODÓ, I.:

Modern evaluation of the weaning weight in a Charolais herd by using individual animal model (Charolais borjak választási súlyának üzemi értékelése egyedi állatmodell alkalmazásával). Hungarian Journal of Animal Production (Állattenyésztés és Takarmányozás) 48 (1998) 6, 503-513

GOYACHE, F.; ROYO, L.J.; ALVAREZ, I.; GUTIERREZ, J.P.:

Testing a continuous variation in preweaning expression of muscular hypertrophy in beef cattle using field data. Arch. Tierz., Dummerstorf 45 (2002), 139-149

JAKUBEC, V.; RIHA, J.; GOLDA, J.; MAJZLÍK, I.:

Analysis of factors affecting pre- and postweaning traits of Angus calves in the Czech Republic. $51^{\text {st }}$. Annual Meeting of European Association for Animal Production. Hague, (2000) 21-24 August

JAKUBEC, V.; SCHLOTE, W.; RIHA, J.; GOLDA, J.; MAJZLÍK, I.:

Comparison of growth traits of eight beef cattle breeds in the Czech Republic. Arch. Tierz., Dummerstorf 46 (2003), 143-153

LEE, C.; POLLAK, E. J.:

Relationship between sire $\mathrm{x}$ year interactions and direct-maternal genetic correlation for weaning weight of Simmental Cattle. J. Anim. Sci., 75 (1997a), 68-75

LEE, C.; POLLAK, E. J.:

Influence of sire misidentification on sire $\mathrm{x}$ year interaction variance and direct-maternal genetic covariance for weaning weight in beef cattle. J. Anim. Sci., 75 (1997b), 2858-2863

MASSEY, M.E.; BENYSHEK, L.L.

Interactions involving sires, breed of dam and age of dam for performance characteristics in Limousin cattle. J. Anim. Sci., 53 (1981) 4, 940-945

MEYER, K.:

Variance components due to direct and maternal effects for growth traits of Australian beef cattle.

Livestock Production Science, 31 (1992), 179-204

NELSEN, T.C.; KRESS, D.D.: 
Additive and multiplicative correction factors for sex and age of dam in beef cattle weaning weight. J. Anim. Sci., 53 (1981) 5, 1217-1224

NÚNEZ-DOMINGUEZ, R.; VAN VLECK, L. D.; BOLDMAN, K. G.; CUNDIFF, L. V.:

Correlations for genetic expression for growth of calves of Hereford and Angus dams using a multivariate animal model. J. Anim. Sci., 71 (1993), 2330-2340

PHOCAS, F.; LALOË, D.:

Evaluation models and genetic parameters for calving difficulty in beef cattle. J. Anim. Sci. 81 (2003), 933-938

REINSCH, N.; KALM, E.:

Genfluss und relative Bedeutung maternaler, paternaler und direkter Effekte beim Milchrind. Arch. Tierz., Dummerstorf 38 (1995), 353-366

SZABÓ, F.; GAJDI, J.:

Some effects on weaning weight of Hereford calves in extensive conditions (Néhány tényező hatása a hereford borjak választási tömegére) Hungarian Journal of Animal Production (Állattenyésztés és SZABÓ, F.: Takarmányozás) 42 (1993) 6, 499-505

Population genetic analyses of beef catle breed differences. (Fajtakülönbségek populációgenetikai elemzése a húsmarha tenyésztésben) DsC Dissertation (Akadémiai Doktori értekezés) 1993

SZABÓ, F.; LENGYEL, Z.; WAGENHOFFER, ZS.; DOHY, J.:

Population genetic parameters of beef cattle 1st paper: Heritability values of the most important traits (A húsmarhatenyésztés populációgenetikai paraméterei. 1 közlemény: A fontosabb tulajdonságok örökölhetősége) Hungarian Journal of Animal Production (Állattenyésztés és Takarmányozás) 49 (2001) 3, 193-205

TÖZSÉR, J.; BALIKA, S.; KOMLÓSI, I.:

Estimation de l' héritabilité du poids vif au sevrage pour la race Limousine. 9 émes Rencontre Recherches Ruminants, Paris. (2002) 9, 97

VAN VLECK, L.D.; GREGORY, K.E.; BENETT, G.L.:

Direct and maternal covariances by age of dam for weaning weight. J. Anim. Sci., 74 (1996), 18011805

VARONA, L.; MISZTAL, I.; BERTRAND, K.L.:

Treshold-Linear versus linear-linear analysis of birth weight and calving ease using animal model: I. Variance component estimation. J. Anim. Sci., 77 (1999), 1994-2002

WILLHAM, R.L.:

The role of maternal effects in animal breeding: III. Biometrical aspects of maternal effects in animals. J. Anim. Sci., 35 (1972), 1288-1293

Received: 2006-08-17

Accepted: 2007-05-13

Authors' addresses

FERENC SZABÓ DSc*, ZOLTÁN LENGYEL PhD, SZABOLCS BENE

Department of Animal Science and Production

University of Pannonia, Georgikon Faculty of Agricultural Science

Deák F. str. 16. H-8360, KESZTHELY, HUNGARY

*Corresponding Author

E-Mail: szf@georgikon.hu

ZOLTÁN DOMOKOS

Association of Hungarian Charolais Breeders

Vologda str. 3. H-3525, MISKOLC, HUNGARY 